lereerst van de gebruikte beelden en vervolgens van de verhaalstructuren in de bijbel. Dit zijn respectievelijk (zie de omkering in vergelijking met het eerste deel) de hoofdstukken 'typologie II', 'metafoor II. beeldspraak' en 'mythe II. verhaalvorm'. In het laatste hoofdstuk, en niet het minst belangrijke, 'taal II' gaat Frye opnieuw in op de 'retoriek van de religie'. Hij geeft een schets van een polysemische of meerduidige opvatting van de hermeneutiek zoals die op de bijbel wordt toegepast, en zoals die in de middeleeuwse bijbelexegese een bloeiende beoefening heeft gekend (en zoals trouwens ook Dante toepaste op eigen werk). Dit is een boeiende aangelegenheid, omdat de auteur hier aantoont hoe men op de stijgende ladder der betekenissen opklimt als men wel van de 'letterlijke' betekenis van een mythe of metafoor vertrekt, maar zich niet bij dit 'letterlijke' niveau houdt, en men dus ook de allegorische, de morele en anagogische niveau's doorloopt.

Dit boek van Northrop Frye is een schitterende inleiding tot de hermeneutiek; het is een praktische toepassing van het meer theoretische werk van Gadamer en Ricoeur, en tegelijk betekent het een didaktische illustratie en toelichting van de literaire werkzaamheid van de bijbel, een werk dat op onze verbeeldingswereld zo'n merkwaardige invloed heeft uitgeoefend. Dit werk van Frye richt zich zeker niet de tot specialist van de bijbelexegese, ook niet tot diegene die in de bijbel en in de geschiedenis van de spiritualiteit niets anders dan restanten van te vergeten beschavingen ziet. Het boek richt zich veeleer tot diegene die in onze geseculariseerde beschaving iets meer van zijn eigen wortels wil terugvinden.

Jacques DE VISSCHER

***

\title{
EEN REFLECTIE OP DE RATIONALITEIT
}

A. Burms en H. De Dijn, De rationaliteit en haar grenzen. Kritiek en deconstructie, AssenVan Goum \& U.P.-Leuven, Leuven 1986, 105 p. ISBN 9061862000.

'Rationaliteit', rationeel denken schijnt de dag van vandaag een soort van toverwoord te zijn dat een betrouwbare benadering van de werkelijkheid moet waarborgen. Dit gaat zo ver dat in bepaalde positivistische en/of rationalistische kringen enkel datgene als relevant wordt aangezien dat een rationeel fundament heeft. In een boeiend geschrift, De rationaliteit en haar grenzem, argumenteren de twee Leuvense filosofen, A. Burms en H. De Dijn tegen de mening in dat de rationaliteit een beperktheid bezit, dat het met name onmogelijk is "om als het ware van buitenaf of op 'rationele' wijze datgene te funderen waardoor mensen aan hun leven zin of waarde geven" (p. VI).

Dit inzicht ontplooien ze op een logische manier. In een eerste hoofdstuk, vergelijken de auteurs drie grote categorieën of interessesferen waarin de bewuste motieven, die het menselijk gedrag bepalen, kunnen ondergebracht worden, namelijk de manipulatieve of de interesse om de werkelijkheid te transformeren in een nuttig geachte zin, de cognitieve of het verlangen de realiteit te kennen en tenslotte de zingevende interesse. Met nadruk wijzen zij hierbij op het eigen karakter van de zingeving die niet mag gezien worden als een sub- 
tiele variante van de twee vorige, integendeel. In het geheel van het menselijk leven, neemt het zingevende een centrale plaats in waardoor het ook zijn schaduw werpt op de "ongeremde menselijke drang om te weten en te manipuleren". (p. 11)

In onze cultuur echter botst dit inzicht op taai verzet. Heel wat filosofen en wetenschappers willen immers het zingevende tot het cognitieve reduceren. In een tweede hoofdstuk wordt de historische basis van deze weerstand uiteengezet. Een scharnierperiode is de eeuw van de Verlichting. In de Middeleeuwen, menen de auteurs, vindt "het theoretisch denken zijn maatstaf en begrenzing in een ideaal van wijsheid of in een hulde van het intellect aan datgene wat het intellect overstijgt en wat dient vereerd te worden". (p. 15) Deze noodzakelijke vertrouwdheid met de eigenheid van een specifieke cultuur om het denken binnen die cultuur te begrijpen, wordt opgegeven vanaf de Moderne Tijd en vervangen door het 'individuele' denken. V anaf Bacon, Descartes, Galilei en Newton wordt een inzicht nagestreefd dat in principe toegankelijk moet zijn voor elk redelijk individu. Wetenschap is op die manier cultuuronafhankelijk. In het spoor van deze 'ontvoogding' van wetenschap en van individu heeft men een ideologie van behoeften gelanceerd waarin de idee dat "alleen geluk waardevol is" een centrale plaats inneemt. Zoals de schrijvers echter aantonen, verwaarloost deze individualistische ideologie de zingevende interesse van de mens. Terecht wijzen zij erop dat "menselijke verlangens in onverbrekelijke relatie staan met cultureel bepaalde betekenissen". (p. 24)

$\mathrm{Na}$ de afwijzing van het individualisme, gaat men dieper in op de draagwijdte van de 'zingeving'. Belangrijk is hier de idee dat elke ervaring van zin gekenmerkt wordt door "een inherente dubbelheid of gespletenheid". (p. 31) Aan de ene kant willen we ons toeëigenen wat ons treft of bekoort, maar aan de andere kant ervaren we datgene wat ons het diepst ontroert steeds als 'transcendent', dit wil zeggen als gedeeltelijk onafhankelijk van de effecten die het op ons heeft. Deze karakteristiek van de zinservaring brengt dus mee dat in de zingeving steeds het risico van zinverlies besloten ligt. Diezelfde ambiguïteit menen de auteurs ook terug te vinden in de deconstructionistische denkrichting van de Franse filosoof Jacques Derrida.

Draagt de zingeving door haar transcendent karakter steeds een onbekend element in zich, dan wil de moderne wetenschap deze onzekerheid voor de mens wegnemen. Dit wordt besproken in een vierde hoofdstuk Wetenschap en zingeving. Nadat de wetenschapper heeft vastgesteld dat de wereld van de wetenschap en de 'Lebenswelt' grondig van elkaar verschillen, ontstaat een nieuw antropocentrisme waarin men probeert aan te tonen dat de wetenschap helemaal niet bevreemdend moet zijn en "zelfs een rechtv aardiging kan bieden voor allerlei morele of religieuze waarden". (p. 47) Door het fundamenteel verschillend karakter van beide interessesferen, is deze poging gedoemd om te mislukken.

De discrepantie tussen beide interessesferen belichten de auteurs verder in een bespreking van de wetenschap versus de realiteit. De auteurs vertrekken van de controverse omtrent de overeenstemming tussen wetenschap en realiteit die in feite zou handelen over de zin van de wetenschap. Deze poging om via discussies over wetenschappelijk realisme te komen tot conclusies omtrent de zin van de wetenschap, noemen de schrijvers één van de vele uitingen van de menselijke drang om aan de ervaring van zin een cognitieve betekenis te geven (p. 67), een gegeven dat zelf voortkomt uit een diepe weigering om de radicale transcendentie te aanvaarden. 
In een laatste hoofdstuk komt vooral de verhouding tussen zingeving en manipulatie aan bod. Het groeit uit een pregnante cultuurkritiek op de huidige rol van de techniek.

Dit werk is ongetwijfeld een boeiende studie die belangrijke facetten van onze cultuur omspant: zo het probleem van de zingeving, van de rol die de wetenschap kan of niet mag spelen, het vraagstuk van de fascinatie die uitgaat van de moderne techniek, de relatie tussen religie en wetenschap, enzovoort. Bekijkt men het rijtje van onderwerpen, dan kan men zich toch de vraag stellen of de auteurs niet te veel hooi op hun vork hebben genomen, zeker wanneer dit alles samengeperst zit op amper honderd pagina's. Dit is opvallend in het laatste hoofdstuk waar op een drafje een hele cultuurkritiek wordt afgehandeld. Afgezien van deze aanmerking, die ik wil catalogeren als een schoonheidsfoutje, zijn er toch een paar meer fundamentele bedenkingen. Zo is er het gebruik van het begrip transcendent in de zingevende interesse. De auteurs plaatsen dit in het hart van de zingeving, dit in tegenstelling tot de wetenschappelijke of cognitieve interesse. Kan deze mening wel overeind blijven? De wetenschap wordt toch ook steeds geconfronteerd met een werkelijkheid die ten overstaan van de wetenschappelijke kennis, transcendent is. Was dit niet het geval dan zou, zoals Delfgəauw het uitdrukt, de wetenschap een einde hebben gevonden. De auteurs schijnen dit maar gedeeltelijk in hun betoog te hebben opgenomen en hebben er zeker niet de conclusie uit getrokken dat op dit punt geen wezenlijk verschil bestaat tussen de zingevende en cognitieve interesse. De uitspraak die zij in de mond leggen van "een woordvoerder van het nieuwe antropocentrisme" (p. 47), namelijk dat "als men maar ver genoeg gaat in het streng wetenschappelijk denken, dan zal men niet vervreemd geraken van de vertrouwde waarden, maar dan zal men juist dankzij wetenschappelijk inzicht een objectieve basis kunnen geven aan deze waarden", lijkt mij nogal karikaturaal. Een volgende bedenking betreft het feit dat in de bespreking van de zingevende interesse, weinig of geen rekening wordt gehouden met datgene wat die interesse uitlokt. Staat de mens als zingevend wezen tegenover een zinloze omgeving of kan hij pas als zodanig optreden tegenover een werkelijkheid waaraan reeds zin gegegeven is? Of, zoals Van Melsen het formuleerde in zijn Natuurwetenschap en techniek, sluit niet elke zingeving zinsontlening in?

Wellicht was de beperkte omvang van het boek mee de oorzaak dat een aantal vragen die de auteurs zelf oproepen, niet of slechts onvolledig konden worden behandeld. Maar ondanks deze beperktheid blijft het werk een stimulerend en interessante studie.

Raoul BAUER

\section{DE 'WIENER KREIS'}

Moritz Schlick, The Problems of Philosophy in Their Interconnection, Winter Semester Lectures 1933-34, (uitgegeven door Henk L. Mulder, A. J. Kox en Rainer Hegselmann), Dordrecht, Reidel, 1987, (Vienna Circle Collection volume 18), 224 blz., 185 Hfl. ISBN 9027724652 